\title{
Utility of Enaminonitriles in Heterocyclic Synthesis: Synthesis and Antimicrobial Activity of Some New Azole and Azine Derivatives
}

\author{
Ahmed A. Fadda ${ }^{1, *}$, Adel A.-H. Abdel-Rahman², Ezzat A. Hamed ${ }^{3}$, Ekbal H. Khalil ${ }^{2}$ \\ ${ }^{1}$ Chemistry Department, Faculty of Science, Mansoura University, Mansoura, 35516, Egypt \\ ${ }^{2}$ Chemistry Department, Faculty of Science, Menoufia University, Menoufia, Egypt \\ ${ }^{3}$ Chemistry Department, Faculty of Science, Alexandria University, Alexandria, Egypt
}

\begin{abstract}
Reactions of 6-amino-3-methyl-1,4-diphenyl-1,4-dihydropyrano[2,3-c]pyrazole-5-carbonitrile (1) with a variety of reagents leads to the synthesis of pyrano[2,3-c]pyrazole derivatives has been investigated with the aim to explore the use of this exceptionally reactive nitrile in heterocyclic synthesis.
\end{abstract}

Keywords Dihydropyrano[2,3-c]pyrazole, Enaminonitriles, Azoles, Pyrimidines, Pyridines

\section{Introduction}

Previous papers have shown that pyran derivatives possess pronounced chemical and biological properties[1-3]. On the other hand, substituted pyridines show acaricidal, insecticidal and herbicidal activities[4]. Moreover, pyrimidines are important analgesic and anti-inflammatory agents $[5,6]$. Compounds having a combination of cyclohexylpyran with pyridine and/or pyrimidine moieties can be expected to possess medicinal properties. In addition, some compounds of this class, notably 3-phenylcoumarin containing an azole ring have found applications as fluorescent brightening agent [7]. In contrast to most other types of tumer inhibitory compounds, many of which exhibit toxicity, mutagenicity and other undesirable properties, the pyranopyridine and pyranopyrimidine compounds tend to show minimal side effects. The formation of a new fused heterocyclic ring is an important task for heterocyclic chemists from various points of view.

Also, o-aminonitriles and their versatile role as synthetic intermediates are ideally suited since they consist of multifunctional building unite for new and promising compounds in one or two easy reaction steps. In the last few years Fadda et al., has been involved in an exploration of the potential of activated nitriles in heterocyclic synthesis [8-12]. From these above facts and as part of our program, the reactivity of 6-amino-3-methyl-1,4-diphenyl-1,4-dihydropyrano[2,3-c] pyrazole-5-carbonitrile (1) towards a variety of reagents has been investigated with the aim to explore the use of this

* Corresponding author:

afadda2@yahoo.com (Ahmed A. Fadda)

Published online at http://journal.sapub.org/ajoc

Copyright (C) 2012 Scientific \& Academic Publishing. All Rights Reserved exceptionally reactive nitrile in heterocyclic synthesis.

\section{Results and Discussion}

\subsection{Chemistry}

The synthetic procedures adopted to obtain the target compounds are depicted in Schemes 1-3. The starting 6-amino-3-methyl-1,4-diphenyl-1,4-dihydropyrano-[2,3-c]p yrazole-5-carbonitrile (1) was prepared according to the previously reported methods[13,14]. It is well known that, activation of cyanoacetic acid by conversion to the mixed anhydride with acetic anhydride has been used[15-18] but the generality, simplicity and usefulness has not been appreciated and the reagent has infrequently been used for $N$-acetylations of e.g. urea and $C$-acetylation of enamines [19]. Other activation procedures, such as conversion to cyanoacetyl chloride have also been used, albeit this reagent is notorious for its tendency to self polymerization, particularly when heated[20]. However, heating of cyanoacetic acid together with dihydropyrano[2,3-c]pyrazole derivative 1 in acetic anhydride gave the desired product in an excellent yields of acetamide derivative 2 as a readily collectable precipitate. Thus, it was found that refluxing of ethanolic solution of 1 with hydrazine hydrate in presence of a catalytic amount of piperidine yielded the corresponding 3-amino-1,4,7-trihydro-5-methyl-4,7-diphenyl-pyrazolo[3', $\left.4^{\prime}, 2,3\right]$ pyrano[6,5-c]pyrazole (3). Its IR spectrum displayed absorption bands at 3429, 3264 and $3095 \mathrm{~cm}^{-1}$ due to $\mathrm{NH}_{2}$ and $\mathrm{NH}$ groups and showed no absorption at the $\mathrm{CN}$ region. Also, the structure of 3 was judged by mass spectrum, it showed the molecular ion peak at $\mathrm{m} / \mathrm{z} 344\left(\mathrm{M}^{+}+1,41.2\right)$ which is in agreement with its molecular formula $\left(\mathrm{C}_{20} \mathrm{H}_{17} \mathrm{~N}_{5} \mathrm{O}\right)$. The reaction proposed to proceed by addition 
of hydrazine molecule to the cyano group which followed by loss of ammonia molecule during refluxing for prolonged time with the formation of the isolable product 3 .

Similarly, heating an equimolar mixture of 1 and $o$ phenylenediamine, $o$-aminophenol or $o$-aminothiophenol in absolute ethanol in the presence of catalytic amount of piperidine for long time afforded the corresponding 5(1H-benzo[d](imidazol/oxazol /or thiazole)-2-yl)-3-methyl1,4-diphenyl-1,4-dihydro-pyrano[2,3-c]pyrazol-6-amine derivatives 4,5 and 6 , respectively. The reaction proceeds by initial addition of hydrogen to cyano group, which then undergoes intramolecular cyclization via loss of $\mathrm{NH}_{3}$ molecule which led to formation of the final products 4,5 and 6 , respectively (Scheme 1). Structures 4, 5 and 6 were established by the correct analyses and compatible spectroscopic data. In general, the IR spectra showed an absorption band at $3388-3190 \mathrm{~cm}^{-1}$ due to the stretching frequency of the $\mathrm{NH}_{2}$ group and the disappearance of $\mathrm{CN}$ group while in the ${ }^{1} \mathrm{H}$-NMR spectra of compounds 4 and 5 the $\mathrm{NH}_{2}$ protons appeared at $\delta 8.18$ and $7.54 \mathrm{ppm}$, respectively as singlet signals. In addition, the mass spectroscopic measurement for compounds 4,5 and 6 showed the molecular ion peaks at $\mathrm{m} / \mathrm{z}$ $418\left(\mathrm{M}^{+}-1,12.5\right), 420\left(\mathrm{M}^{+}, 13.3\right)$ and $421\left(\mathrm{M}^{+}-\mathrm{CH}_{3}, 17.6\right)$, respectively.

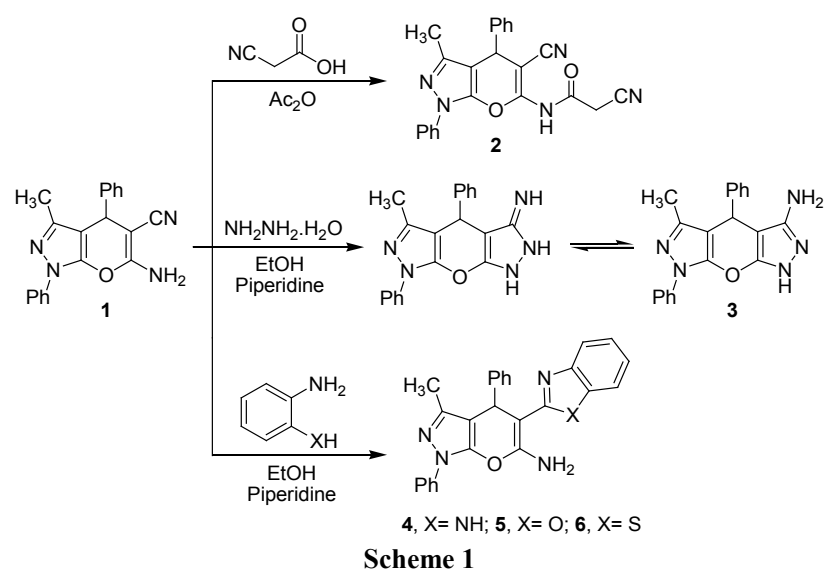

Many condensed heterocyclic systems especially when linked to a pyrimidine ring play an important role as analgesic, antihypertensive, antipyretic, anti-inflammatory drugs, also as pesticides, herbicides and plant growth regulators $[21,22]$. Furthermore, the chromeno[2,3- $d]$ pyrimidine and pyranopyrimidine[23], ring systems has gained biological interest due to the formal isoelectronic relation between this ring and purine[24]. These observations attracted our attention to synthesize some of these new products with expected biological activity.

The reactions of o-aminonitriles with urea and thiourea, were reported to afford condensed 4-aminopyrimidin-2-one and 4-aminopyrimidin-2-thione derivatives, respectively[25, 26]. Therefore, refluxing of compound 1 with urea or thiourea in absolute ethanol in the presence of sodium ethoxide afforded 5-amino-4,8,9-trihydro-3-methyl-1,4-diphenyl pyrazolo[3',4',2,3]pyrano[6,5-d]pyrimidine-7-one(thione) derivatives 7 and 8 , respectively. The structure of products 7 and 8 were further assignment by both elemental analyses and spectroscopic measurements. The ${ }^{1} \mathrm{H}$ NMR revealed peaks at $\delta 5.61$ and $4.78 \mathrm{ppm}$ corresponding to the $\mathrm{NH}_{2}$ protons and singlet signals at $\delta 7.54 \mathrm{ppm}$ for $\mathrm{NH}$ protons, while the mass spectrum showed the molecular ion peaks at $\mathrm{m} / \mathrm{z} 371\left(\mathrm{M}^{+}, 0.29\right)$ and $372\left(\mathrm{M}^{+}-\mathrm{CH}_{3}, 58.3\right)$, respectively. A fused pyrazolo[3',4',2,3]pyrano[6,5- $d]$ thiazine-2-thione derivative 9 is synthesized by reaction of dihydropyrano[2,3-c] pyrazole derivative 1 with carbon disulphide. Thus, when 1 and carbon disulphide were refluxed in pyridine gave compound 9 via the intermediate (A) (Scheme 2). Compound 9 gave correct values in elemental analyses and displayed no absorption band at the $\mathrm{CN}$ region in its IR spectrum. Also, the mass spectrum showed the molecular ion peak at $\mathrm{m} / \mathrm{z} 405$ $\left(\mathrm{M}^{+}+1,1.58\right)$.

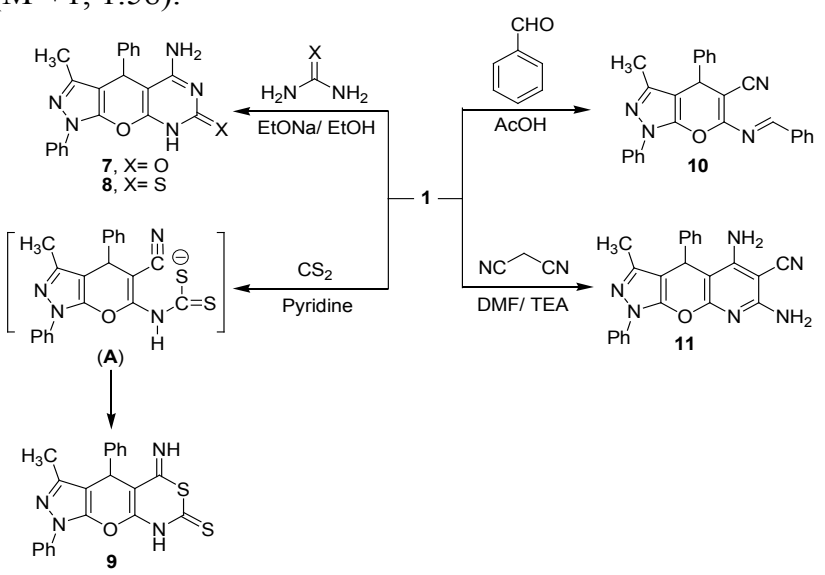

Scheme 2

Condensation of dihydropyrano[2,3-c]pyrazole 1 with benzaldehyde afforded the $N$-condensation product 6- (benzylideneamino)-3-methyl-1,4-diphenyl-1,4-dihydro-pyrano[ 2,3-c]pyrazole-5-carbonitrile (10). Structure was confirmed by analytical as well as spectral data. Condensed 5,7- diamino-6-cyano-4,9-dihydro-3-methyl-1,4-diphenyl-pyrazolo[ $\left.3^{\prime}, 4{ }^{\prime}, 2,3\right]$ pyrano[6,5-b]pyridine (11) is readily prepared by the reaction of 1 with malononitrile in DMF containing a catalytic amount of TEA. The IR spectrum of compound 11 showed absorption band at $3128,3026,2193 \mathrm{~cm}^{-1}$ due to $\mathrm{NH}_{2}$ and nitrile function, while it's ${ }^{1} \mathrm{H}$ NMR spectrum revealed peaks at $\delta 6.94$ and 7.14 as singlet signals corresponding to two amino groups' protons (Scheme 2).

Compound 1 reacted also with phenacyl cyanide to afford 5-amino-6-cyano-4,9-dihydro-3-methyl-1,4,7-triphenyl pyra zolo[3', $\left.4^{\prime}, 2,3\right]$ pyrano[6,5-b]pyridine (12) on refluxing in DMF containing a catalytic amount of piperidine for $6 \mathrm{~h}$. On the other hand, compound 12 could be obtained by another route via reaction of 1 with benzylidene malononitrile in DMF catalyzed by a catalytic amount piperidine on refluxing for $6 \mathrm{~h}$. The reaction is thought to proceed via the sequence shown in the following synthetic route (Scheme 3). The IR spectrum of 12 displayed absorption band at $3134,3039 \mathrm{~cm}^{-1}$ $\left(\mathrm{NH}_{2}\right)$ and $2183 \mathrm{~cm}^{-1}(\mathrm{CN})$. Combination of ${ }^{1} \mathrm{H}$ NMR and correct values of elemental analyses confirmed the cyclized structure 12 . 
In addition, refluxing ethanolic solution of 1 with the phenacyl bromide in the presence of anhydrous potassium carbonate afforded the $N$-phenacyl derivative 13 which could not be cyclized further. The IR spectrum of compound 13 showed an absorption bands at 3657, 2196 and $1661 \mathrm{~cm}^{-1}$ characteristic for $\mathrm{NH}, \mathrm{CN}$ and $\mathrm{CO}$ functions, respectively. Moreover, the ${ }^{1} \mathrm{H}$ NMR revealed four singlet signals at $\delta$ $1.95,3.8,5.48$ and $8.29 \mathrm{ppm}$ due to methyl, methylene, methine and $\mathrm{NH}$ protons, respectively.

Several reactions for both aromatic and heterocyclic $o$-aminonitriles with formic acid and with the usual acylating agents have been reported[27]. The $o$-formyl or the $o$-acylaminonitriles so formed are of considerable interest because of their conversion by acid or base to the corresponding pyrimidines. Thus, it has been found that, compound 1 reacted with formic acid in absolute ethanol followed by oxidation to afford the corresponding pyrimidine4-one 16 upon treatment with alkaline hydrogen peroxide of the intermediate 14 . The reaction proceeds by initial hydration of the nitrile group to the carboxamide, which then undergoes cyclization in alkaline medium. In addition, when the dihydro-pyrano[2,3-c]pyrazole 1 was refluxed in dimethylformamide with formamide in the presence of a catalytic amount of piperidine, the product 5-amino-4,9dihydro-3-methyl-1,4-diphenyl pyrazolo[3',4',2,3]pyrano[6, $5-d]$ pyrimidine (17) was isolated. Thus, from the IR spectrum, no absorption band for the cyano group was observed (Scheme 3).

The newly synthesized compounds were established on the basis of their elemental analyses and spectral data (IR, ${ }^{1}$ H-NMR and mass spectral data, C.f. Experimental section).

\subsection{Antimicrobial Activity}

The antimicrobial activity of the synthesized compounds was evaluated against three microorganisms; Bacillus sub- tilis (ATCC 6633) (Gram-positive), Pseudomonas aeruginosa (ATCC 27853) (Gram-negative) and Streptomyces species (Actinomycetes). The values of minimal inhibitory concentrations (MICs) of the tested compounds are presented in Table 1. The results of the antimicrobial activity test revealed that 3,8 , and 13 showed the highest activity against $B$. subtilis with MIC values of $75 \mu \mathrm{g} / \mathrm{mL}$ followed by compounds 11,12 , and 17 . Compound 3 showed the highest inhibition activity against $P$. aeruginosa, whereas compound 11 was the most active among the series of tested compounds against Streptomyces species with MIC values of $75 \mu \mathrm{g} / \mathrm{mL}$. The results also revealed that some compounds showed little or no activity against the microorganisms (Table 1).

Table 1. Minimum inhibitory concentrations (MIC in $\mu \mathrm{g} / \mathrm{mL}$ ) of the title compounds, the negative control DMSO showed no activity

\begin{tabular}{|c|c|c|c|}
\hline $\begin{array}{c}\text { Compound } \\
\text { No. }\end{array}$ & $\begin{array}{c}\text { Gram- } \\
\text { positive } \\
\text { B. subtilis }\end{array}$ & $\begin{array}{l}\text { Gram-negative } \\
P . \text { aeruginosa }\end{array}$ & $\begin{array}{c}\text { Actinomycetes } \\
\text { Streptomyces } \\
\text { specie }\end{array}$ \\
\hline 3 & 75 & 75 & 125 \\
\hline 4 & 250 & $-^{\mathrm{a}}$ & 500 \\
\hline 5 & 125 & 100 & 100 \\
\hline 6 & 125 & 500 & -- \\
\hline 7 & 250 & 100 & 125 \\
\hline 8 & 75 & 125 & 100 \\
\hline 9 & -- & 250 & 125 \\
\hline 10 & 125 & 100 & 250 \\
\hline 11 & 100 & -- & 75 \\
\hline 12 & 100 & 125 & -- \\
\hline 13 & 75 & 100 & 125 \\
\hline 16 & 250 & 500 & 100 \\
\hline 17 & 100 & 125 & 125 \\
\hline Penicillin & 31 & 46 & 33 \\
\hline
\end{tabular}

${ }^{\text {a }}$ Totally inactive (MIC $\left.>500 \mu \mathrm{g} / \mathrm{mL}\right)$.<smiles></smiles><smiles>CCOC(=O)C(CBr)c1ccccc1-c1ccccc1</smiles>

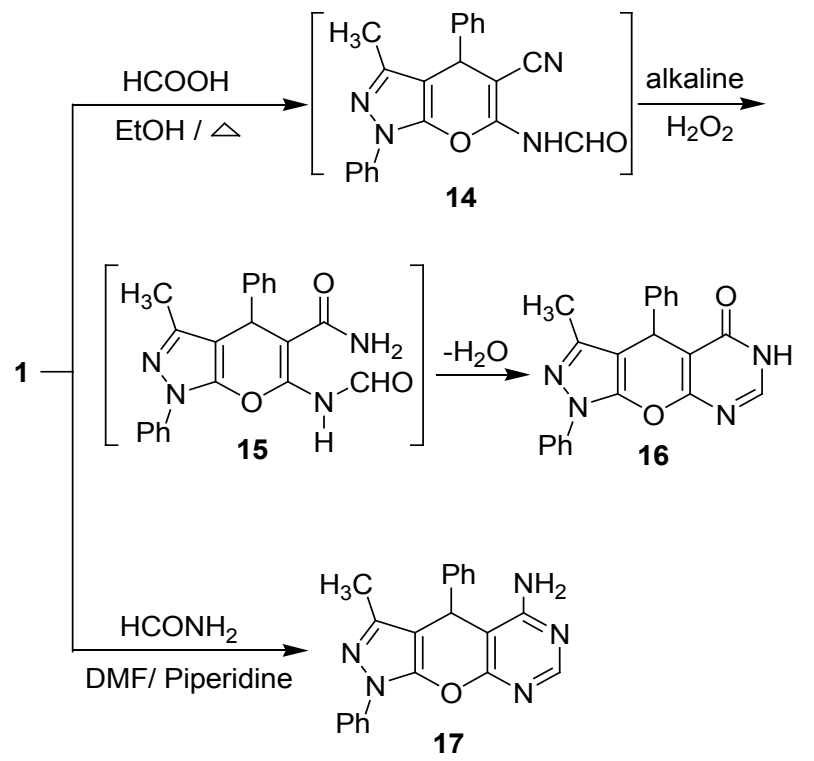

Scheme 3 


\section{Experimental}

All melting points are recorded on Gallenkamp electric melting point apparatus. The IR spectra $v \mathrm{~cm}^{-1}(\mathrm{KBr})$ were on Perkin Elmer Infrared Spectrophotometer Model 157, Grating. The 1H-NMR spectra were run on Varian Spectrophotometer at $400 \mathrm{MHz}$ using TMS as an internal reference and DMSO- $d_{6}$ as solvent. The mass spectra (EI) were run at 70 eV with JEOL JMS600 equipment and/or a Varian MAT 311 A Spectrometer. Elemental analyses $(\mathrm{C}, \mathrm{H}$ and $\mathrm{N})$ were carried out at the Microanalytical Center of Cairo University, Giza, Egypt. The results were found to be in good agreement $( \pm 0.3 \%)$ with the calculated values. 6-Amino-3-methyl-1,4diphenyl-1,4-dihydropyrano[2,3-c]pyrazole-5-carbonitrile

(1) was prepared according to the previously reported methods $[13,14]$ as white needles, mp $179-180^{\circ} \mathrm{C}$; $79 \%$; IR (KBr): $v / \mathrm{cm}^{-1}=3470,3322(\mathrm{NH} 2), 2197(\mathrm{CN}), 1659(\mathrm{C}=\mathrm{N})$, $1592(\mathrm{C}=\mathrm{C}), 1491(\mathrm{Ph}) ; \mathrm{MS}: \mathrm{m} / \mathrm{z}(\%): 328\left(\mathrm{M}^{+}, 13.12\right), 262$ (0.22), 251 (83.5), 185 (93.8), 174 (20.3), 154 (17.0), 127 (23.8), 91 (20.0), 77 (46.2), 66 (21.9).

Synthesis of 2-cyano- $\mathrm{N}$-(5-cyano-3-methyl-1,4-diphen yl-1,4-dihydropyrano[2,3-c]pyrazol-6-yl)acetamide (2). A solution of cyanoacetic acid $(5 \mathrm{mmol})$ in acetic anhydride $(15 \mathrm{~mL})$ was heated under reflux over water bath for $5 \mathrm{~min}$ utes and dihydropyrano[2,3-c]pyrazole derivative 1 (5 mmol) was added. The reaction mixture was refluxed for further $1 \mathrm{~h}$ at $60-70^{\circ} \mathrm{C}$, and then left to cool. The precipitated solid was filtered off, dried and recrystallized from ethanol to give acetamide derivative 2 . Yield (54\%); brown powder; mp $125^{\circ} \mathrm{C}$; IR (KBr): $v / \mathrm{cm}^{-1}=3395(\mathrm{NH}), 2926(\mathrm{CH}$, aliphatic), 2192 (CN), 1598 (CO, amidic), $1498(\mathrm{Ph}) ;{ }^{1} \mathrm{H}-\mathrm{NMR}(200$ $\left.\mathrm{MHz}, \mathrm{CDCl}_{3}\right) \delta(\mathrm{ppm}): 2.15\left(\mathrm{~s}, 3 \mathrm{H}, \mathrm{CH}_{3}\right), 2.57\left(\mathrm{~s}, 2 \mathrm{H}, \mathrm{CH}_{2}\right)$, $4.79(\mathrm{~s}, 1 \mathrm{H}, \mathrm{CH}), 7.26-7.96(\mathrm{~m}, 10 \mathrm{H}, \mathrm{Ar}-\mathrm{H}), 8.46(\mathrm{~s}, 1 \mathrm{H}$, $\mathrm{NH})$. MS (EI, $70 \mathrm{ev}) \mathrm{m} / \mathrm{z}(\%)=395\left(\mathrm{M}^{+}, 33.3\right), 394\left(\mathrm{M}^{+}-1\right.$, 27.8), 266 (33.3), 233 (33.3), 226 (33.3), 210 (33.3), 211 (33.3), 91 (33.3), 87 (38.9), 68 (55.6), 50 (100.0). Anal. Calcd. for $\mathrm{C}_{23} \mathrm{H}_{17} \mathrm{~N}_{5} \mathrm{O}_{2}$ (395.41): C, 69.86; H, 4.33; N, 17.71\%. Found: C, 69.93; H, 4.37; N, 17.77\%.

Synthesis of 3-amino-1,4,7-trihydro-5-methyl-4,7- diphenyl-pyrazolo $\left[3^{\prime}, 4^{\prime}, 2,3\right]$ pyrano $[6,5-c]$ pyrazole

Equimolar amounts of $(1,5 \mathrm{mmol})$ and hydrazine hydrate $(5$ $\mathrm{mol})$ in absolute ethanol $(30 \mathrm{~mL})$ in presence of a catalytic amount of piperidine (4 drops) was refluxed for $12 \mathrm{~h}$. The reaction mixture was left to cool at room temperature and then poured in to cold water for complete precipitation. The solid products was filtered off and recrystallized from aqueous ethanol to give the corresponding compound 3 . Yield (30.9\%); black crystals; mp $160-162^{\circ} \mathrm{C}$; IR (KBr): $v / \mathrm{cm}^{-1}=3429,3264\left(\mathrm{NH}_{2}\right), 3095(\mathrm{NH}), 1595(\mathrm{C}=\mathrm{N}), 1497$ (Ph). MS (EI, $70 \mathrm{ev}) \mathrm{m} / \mathrm{z}(\%)=344\left(\mathrm{M}^{+}+1,41.2\right), 181(35.5)$, 120 (23.5), 103 (35.5), 82 (41.2), 70 (35.3), 64 (100.0), 53 (41.2). Anal. Calcd. for $\mathrm{C}_{20} \mathrm{H}_{17} \mathrm{~N}_{5} \mathrm{O}$ (343.38): C, 69.96; $\mathrm{H}$, 4.99; N, 20.40\%. Found: C, 70.04; H, 5.06; N, 20.47\%.

Reaction of dihydropyrano[2,3-c]pyrazole derivative 1 with $o$-substituted anilines

General procedure: An equimolar amounts of (1, $5 \mathrm{mmol})$, $o$-phenylenediamine, $o$-aminophenol or $o$-aminothiophenol in absolute ethanol $(30 \mathrm{~mL})$ in the presence of a catalytic amount of piperidine ( 4 drops) was refluxed for $30 \mathrm{~h}$. The reaction mixture was concentrated to its half volume and then left to cool at room temperature overnight. The solid products was filtered off and recrystallized from ethanol to give the corresponding dihydropyrano[2,3-c]pyrazole derivatives 4,5 and 6 , respectively.

5-(1H-Benzo $[d]$ imidazol-2-yl)-3-methyl-1,4-diphenyl-1 ,4-dihydropyrano[2,3-c]pyrazol-6-amine (4). Yield (35.4\%); brown powder; mp $121-125^{\circ} \mathrm{C}$; IR $(\mathrm{KBr}): v / \mathrm{cm}^{-1}=$ 3383, $3360\left(\mathrm{NH}_{2}\right), 3179(\mathrm{NH}), 1658(\mathrm{C}=\mathrm{N}), 1499(\mathrm{Ph})$; ${ }^{1} \mathrm{H}-\mathrm{NMR}\left(200 \mathrm{MHz}, \mathrm{DMSO}-d_{6}\right) \delta$ (ppm): 2.28 (s, 3H, $\left.\mathrm{CH}_{3}\right)$, 4.87 (s, 1H, CH), 7.24-7.81 (m, 14H, Ar-H), $8.18(\mathrm{~s}, 2 \mathrm{H}$, $\left.\mathrm{NH}_{2}\right), 8.32$ (s, 1H, NH). MS (EI, 70 ev) $\mathrm{m} / \mathrm{z}(\%)=418\left(\mathrm{M}^{+}-1\right.$, 12.5), 334 (12.5), 200 (12.5), 186 (16.7), 174 (22.9), 91 (100.0), 50 (29.2). Anal. Calcd. for $\mathrm{C}_{26} \mathrm{H}_{21} \mathrm{~N}_{5} \mathrm{O}$ (419.48): C, 74.44; H, 5.05; N, 16.70\%. Found: C, 74.36; H, 5.01; N, $16.63 \%$.

5-(Benzo $[d]$ oxazol-2-yl)-3-methyl-1,4-diphenyl-1,4-dihydropyrano[2,3-c]pyrazol-6-amine (5). Yield (92.4\%); pale grey powder; $\mathrm{mp} 158^{\circ} \mathrm{C}$; IR $(\mathrm{KBr}): \mathrm{v} / \mathrm{cm}^{-1}=3388,3192$ $\left(\mathrm{NH}_{2}\right), 1594$ (C-O), 1497 (Ph); ${ }^{1} \mathrm{H}-\mathrm{NMR}(200 \mathrm{MHz}$, DMSO- $\left.d_{6}\right) \delta(\mathrm{ppm}): 2.37\left(\mathrm{~s}, 3 \mathrm{H}, \mathrm{CH}_{3}\right), 3.75(\mathrm{~s}, 1 \mathrm{H}, \mathrm{CH})$, 7.16-7.46 (m, 14H, Ar-H), 7.54 (s, 2H, NH N $^{2}$. MS (EI, $70 \mathrm{ev)}$ $\mathrm{m} / \mathrm{z}(\%)=420\left(\mathrm{M}^{+}, 13.3\right), 302$ (42.2), 262 (15.6), 222 (13.3), 185 (22.2), 152 (15.6), 93 (20.0), 77 (100.0). Anal. Calcd. for $\mathrm{C}_{26} \mathrm{H}_{20} \mathrm{~N}_{4} \mathrm{O}_{2}$ (420.46): C, 74.27; H, 4.79; N, 13.33\%. Found: C, 74.34; H, 4.82; N, 13.41\%.

5-(Benzo $[d]$ thiazol-2-yl)-3-methyl-1,4-diphenyl-1,4-dihydropyrano[2,3-c]pyrazol-6-amine (6). Yield (94\%); yellowish green powder; mp $120-122^{\circ} \mathrm{C}$; IR $(\mathrm{KBr}): v / \mathrm{cm}^{-1}=$ : 3387, $3190\left(\mathrm{NH}_{2}\right), 1596(\mathrm{C}=\mathrm{N}), 1497(\mathrm{Ph})$; MS (EI, $70 \mathrm{ev)}$ $\mathrm{m} / \mathrm{z}(\%)=421\left(\mathrm{M}^{+}-\mathrm{CH}_{3}, 17.6\right), 358$ (14.7), 269 (26.5), 268 (100.0), 267 (26.5), 241 (20.6), 211 (38.2), 179 (29.4), 162 (26.5), 134 (47.1), 108 (61.8), 91 (88.2), 69 (70.6). Anal. Calcd. for $\mathrm{C}_{26} \mathrm{H}_{20} \mathrm{~N}_{4} \mathrm{OS}$ (436.53): C, 71.54; H, 4.62; N, $12.83 \%$. Found: C, 71.59; H, 4.67; N, 12.91\%.

Synthesis of 5-amino-4,8,9-trihydro-3-methyl-1,4-di phenyl-pyrazolo $\left[3^{\prime}, 4^{\prime}, 2,3\right]$ pyrano $[6,5-d]$ pyrimidine-7-one (thione) derivatives 7 and 8

General procedure: A mixture of $(1,5 \mathrm{mmol})$ and urea (5 $\mathrm{mmol})$ or thiourea $(5 \mathrm{mmol})$ in absolute ethanol $(20 \mathrm{~mL})$ and sodium ethoxide $(0.023 \mathrm{~g}$ sodium metal in $(20 \mathrm{~mL})$ absolute ethanol, $5 \mathrm{mmol}$ ) was refluxed for $6 \mathrm{~h}$. The reaction mixture was left to cool at room temperature, then poured in to ice cold water $(50 \mathrm{~mL})$ and neutralized with dilute hydrochloric acid. The separated material was filtered off and recrystallized from ethanol to yield compounds 7 and 8, respectively.

5-Amino-4,8,9-trihydro-3-methyl-1,4-diphenyl-pyrazo lo[3', $\left.4^{\prime}, 2,3\right]$ pyrano[6,5-d]pyrimi-dine-7-one (7). Yield $(75.2 \%)$; pale orange powder; $\mathrm{mp} 210^{\circ} \mathrm{C}$; IR $(\mathrm{KBr}): \mathrm{v} / \mathrm{cm}^{-1}=$ $3067(\mathrm{NH}), 1654(\mathrm{C}=\mathrm{O}), 1497(\mathrm{Ph}) ;{ }^{1} \mathrm{H}-\mathrm{NMR}(200 \mathrm{MHz}$, DMSO-d ${ }_{6} \delta(\mathrm{ppm}): 1.57\left(\mathrm{~s}, 3 \mathrm{H}, \mathrm{CH}_{3}\right), 4.48(\mathrm{~s}, 1 \mathrm{H}, \mathrm{CH})$, $5.61\left(\mathrm{~s}, 1 \mathrm{H}, \mathrm{NH}_{2}\right), 7.25-7.53(\mathrm{~m}, 10 \mathrm{H}, \mathrm{Ar}-\mathrm{H}), 7.54(\mathrm{~s}, 2 \mathrm{H}$, $\mathrm{NH})$. MS (EI, $70 \mathrm{ev}) \mathrm{m} / \mathrm{z}(\%)=371\left(\mathrm{M}^{+}, 0.29\right), 262$ (89.86), 185 (100.0), 174 (62.89), 128 (35.85), 105 (14.01), 91 (30.79), 77 (64.58). Anal. Calcd. for $\mathrm{C}_{21} \mathrm{H}_{17} \mathrm{~N}_{5} \mathrm{O}_{2}$ (371.39): $\mathrm{C}$, 
67.91; H, 4.61; N, 18.86\%. Found: C, 67.96; H, 4.65; N, $18.94 \%$.

5-Amino-4,8,9-trihydro-3-methyl-1,4-diphenyl-pyrazo lo $\left[3^{\prime}, 4^{\prime}, 2,3\right]$ pyrano $[6,5-d]$ pyrimi-dine-7-thione (8). Yield (34.4\%); brown powder; $\mathrm{mp} 138-140^{\circ} \mathrm{C}$; IR $(\mathrm{KBr}): \mathrm{v} / \mathrm{cm}^{-1}=$ 3323, $3217\left(\mathrm{NH}_{2}\right), 1625(\mathrm{C}=\mathrm{N}), 1482(\mathrm{Ph}), 1188(\mathrm{C}=\mathrm{S})$; ${ }^{1} \mathrm{H}-\mathrm{NMR}\left(200 \mathrm{MHz}, \mathrm{CDCl}_{3}\right) \delta(\mathrm{ppm}): 2.04\left(\mathrm{~s}, 3 \mathrm{H}, \mathrm{CH}_{3}\right)$, $4.53(\mathrm{~s}, 1 \mathrm{H}, \mathrm{CH}), 4.78(\mathrm{~s}, 1 \mathrm{H}, \mathrm{NH}), 5.65\left(\mathrm{~s}, 2 \mathrm{H}, \mathrm{NH}_{2}\right)$, 7.11-7.60 (m, 10H, Ar-H), 7.54 (s, 2H, NH). MS (EI, $70 \mathrm{ev)}$ $\mathrm{m} / \mathrm{z}(\%)=372\left(\mathrm{M}^{+}-\mathrm{CH}_{3}, 58.3\right), 359$ (58.3), $358(50.0), 345$ (58.3), 298 (58.3), 245 (58.3), 192 (33.3), 174 (25.0), 156 (91.7), 115 (66.7), 78 (100.0), 52 (83.3). Anal. Calcd. for $\mathrm{C}_{21} \mathrm{H}_{17} \mathrm{~N}_{5} \mathrm{OS}(387.46)$ : C, 65.10; H, 4.42; N, 18.08\%. Found: $\mathrm{C}, 65.18 ; \mathrm{H}, 4.49 ; \mathrm{N}, 18.13 \%$.

Synthesis of 4-imino-1,5,9-trihydro-6-methyl-4,7- diphenyl-pyrazolo $\left[3^{\prime}, 4^{\prime}, 2,3\right]$ pyrano $[6,5-d]$ thiazine-2-thione (9). To a solution of $(1,5 \mathrm{mmol})$ in dry pyridine $(30 \mathrm{~mL})$ was added carbon disulphide $(5 \mathrm{mmol})$. The reaction mixture was refluxed on water bath for $6 \mathrm{~h}$, then left to cool at room temperature, poured in to cold water and neutralized with dilute hydrochloric acid for complete precipitation. The obtainable solid was filtered off, washed with water, dried well, and recrystallized from methanol to yield compound 9 . Yield (44.7\%); light yellow powder; mp $140-144^{\circ} \mathrm{C}$; IR $(\mathrm{KBr}): v / \mathrm{cm}^{-1}=3062(2 \mathrm{NH}), 1595(\mathrm{C}=\mathrm{N}), 1497(\mathrm{Ph}), 1180$ $(\mathrm{C}=\mathrm{S}), 757$ (C-S). MS (EI, $70 \mathrm{ev}) \mathrm{m} / \mathrm{z}(\%)=405\left(\mathrm{M}^{+}+1\right.$, 1.58), 358 (3.68), 346 (11.23), 314 (12.46), 276 (3.10), 262 (31.17), 185 (22.64), 174 (23.88), 128 (16.29), 105 (16.97), 91 (35.33), 77 (100.0). Anal. Calcd. for $\mathrm{C}_{21} \mathrm{H}_{16} \mathrm{~N}_{4} \mathrm{OS}_{2}$ (404.51): C, 62.35; H, 3.99; N, 13.85\%. Found: C, 62.42; H, $4.06 ; \mathrm{N}, 13.94 \%$.

Synthesis of 6-(benzylideneamino)-3-methyl-1,4- diphenyl-1,4-dihydro-pyrano[2,3-c]pyrazole-5-carbonitrile (10). A mixture of $(1,5 \mathrm{mmol})$ and benzaldehyde $(5 \mathrm{mmol})$ in glacial acetic acid $(30 \mathrm{~mL})$ was heated under reflux for $1 \mathrm{~h}$, cooled, and poured into crushed ice. The produced solid was filtered off, washed with water, dried well, and recrystallized from a mixture of benzene and petroleum ether (3:1) to yield the corresponding compound 10 . Yield $(74 \%)$; white sheets; $\mathrm{mp} 220^{\circ} \mathrm{C}$; IR $(\mathrm{KBr}): \mathrm{v} / \mathrm{cm}^{-1}=2100(\mathrm{CN}), 1596(\mathrm{C}=\mathrm{N}), 1500$ $(\mathrm{Ph}), 1188(\mathrm{C}=\mathrm{S}) ;{ }^{1} \mathrm{H}-\mathrm{NMR}\left(200 \mathrm{MHz}, \mathrm{DMSO}-d_{6}\right) \delta(\mathrm{ppm})$ : $2.17\left(\mathrm{~s}, 3 \mathrm{H}, \mathrm{CH}_{3}\right), 5.04(\mathrm{~s}, 1 \mathrm{H}, \mathrm{CH}), 6.11(\mathrm{~s}, 1 \mathrm{H}, \mathrm{N}=\mathrm{CH})$, 7.22-7.28 (m, 15H, Ar-H). MS (EI, $70 \mathrm{ev)} \mathrm{m} / \mathrm{z}(\%)=339$ ( $\left.\mathrm{M}^{+}-\mathrm{Ph}, 0.1\right), 304$ (58.99), 286 (8.67), 262 (100.0), 200 (1.89), 185 (38.1), 174 (19.26), 128 (18.9), 106 (35.88), 91 (10.2), 77 (42.74). Anal. Calcd. for $\mathrm{C}_{27} \mathrm{H}_{20} \mathrm{~N}_{4} \mathrm{O}$ (416.47): C, 77.87; H, 4.84; N, 13.45\%. Found: C, 77.95; H, 4.94; N, $13.57 \%$

Synthesis of 5,7-diamino-6-cyano-4,9-dihydro-3methyl-1,4-diphenyl-pyrazolo $\left[3^{\prime}, 4^{\prime}, 2,3\right]$ pyrano[6,5-b]-py ridine (11). To a solution of $(1,5 \mathrm{mmol})$ in DMF $(30 \mathrm{~mL})$ was added malononitrile $(5 \mathrm{mmol})$ followed by few drops of TEA (4 drops). The reaction mixture was reflux for $6 \mathrm{~h}$, left to cool at room temperature overnight and then poured in to cold water $(50 \mathrm{~mL})$. The obtainable solid was filtered off, washed with water, dried well, and recrystallized from ethanol to give compound 11. Yield (98.2\%); yellowish green powder; $\mathrm{mp} 120^{\circ} \mathrm{C}$; IR $(\mathrm{KBr}): \mathrm{v} / \mathrm{cm}^{-1}=3128,3026$ $\left(\mathrm{NH}_{2}\right), 2193(\mathrm{CN}), 1601(\mathrm{C}-\mathrm{O}), 1499(\mathrm{C}=\mathrm{N}), 1499(\mathrm{Ph})$; ${ }^{1} \mathrm{H}-\mathrm{NMR}\left(200 \mathrm{MHz}, \mathrm{DMSO}-d_{6}\right) \delta$ (ppm): $2.47\left(\mathrm{~s}, 3 \mathrm{H}, \mathrm{CH}_{3}\right)$, $3.94(\mathrm{~s}, 1 \mathrm{H}, \mathrm{CH}), 6.94\left(\mathrm{~s}, 2 \mathrm{H}, \mathrm{NH}_{2}\right), 7.14\left(\mathrm{~s}, 2 \mathrm{H}, \mathrm{NH}_{2}\right)$, 7.38-7.48 (m, 10H, Ar-H). MS (EI, $70 \mathrm{ev}) \mathrm{m} / \mathrm{z}(\%)=350$ $\left[\mathrm{M}^{+}-2-\left(\mathrm{N}=\mathrm{C}-\mathrm{NH}_{2}\right), 1.0\right], 284$ (100.0), 257 (16.1), 230 (7.95), 219 (8.3), 203 (6.42), 165 (20.71), 138 (5.11), 115 (2.22), 77 (7.33), 66 (5.45). Anal. Calcd. for $\mathrm{C}_{23} \mathrm{H}_{18} \mathrm{~N}_{6} \mathrm{O}$ (394.43): $\mathrm{C}$, $70.04 ; \mathrm{H}, 4.60 ; \mathrm{N}, 21.31 \%$. Found: C, 70.11; H, 4.67; N, $21.38 \%$.

Synthesis of 5-amino-6-cyano-4,9-dihydro-3-methyl1,4,7-triphenyl-pyrazolo $\left[3^{\prime}, 44^{\prime}, 2,3\right]$ pyrano[6,5-b]pyridine (12).

Method A. To a solution of $(1,5 \mathrm{mmol})$ in DMF $(30 \mathrm{~mL})$ was added phenacylcyanide $(5 \mathrm{mmol})$ followed by a few drops of piperidine. The reaction mixture was reflux for $6 \mathrm{~h}$, cold, poured in to ice-cold water for complete precipitation and neutralized by dil. $\mathrm{HCl}$ for complete precipitation. The precipitated solid was collected by filtration, and recrystallized from aqueous ethanol to yield compound 12. Yield (42.7\%); brown powder; $\mathrm{mp} 135^{\circ} \mathrm{C}$; IR $(\mathrm{KBr}): \mathrm{v} / \mathrm{cm}^{-1}=3134$, $3039\left(\mathrm{NH}_{2}\right), 2183(\mathrm{CN}), 1596(\mathrm{C}-\mathrm{O}), 1497(\mathrm{Ph})$. MS (EI, 70 ev) $\mathrm{m} / \mathrm{z}(\%)=454\left(\mathrm{M}^{+}-1,4.9\right), 453\left(\mathrm{M}^{+}-2,15.72\right), 452\left(\mathrm{M}^{+}-3\right.$, 14.88), 399 (5.14), 382 (5.59), 301 (12.6), 262 (76.7), 185 (64.3), 174 (39.2), 128 (27.1), 105 (21.4), 91 (81.8), 77 (100.0). Anal. Calcd. for $\mathrm{C}_{29} \mathrm{H}_{21} \mathrm{~N}_{5} \mathrm{O}$ (455.51): C, 76.47; H, 4.65; N, 15.37\%. Found: C, 76.52; H, 4.71; N, 15.42\%.

Method B. An equimolar amounts of $(1,5 \mathrm{mmol})$ and benzylidine malononitrile $(5 \mathrm{mmol})$ was refluxed for $6 \mathrm{~h}$ in a mixture of DMF in the presence of few drops of piperidine (4 drops). The reaction mixture was left to cool, poured into ice-cold water for complete precipitation, then filtered off and recrystallized from aqueous ethanol to yield compound 12.

Synthesis of 3-methyl-6-(2-oxo-2-phenylethylamino)1,4-diphenyl-1,4-dihydropyrano[2,3-c]pyrazole-5-carbo nitrile (13). A mixture of $(1,5 \mathrm{mmol})$ and phenacyl bromide $(5 \mathrm{mmol})$ in absolute ethanol $(30 \mathrm{~mL})$ in presence of anhydrous potassium carbonate $(5 \mathrm{mmol})$ as a catalyst was refluxed for $3 \mathrm{~h}$. The reaction mixture was left to cool at room temperature overnight. The separated material was filtered off and recrystallized from ethanol to yield compound 13 . Yield (43.4\%); brown powder; mp $126-128^{\circ} \mathrm{C}$; IR ( $\left.\mathrm{KBr}\right)$ : $v / \mathrm{cm}^{-1}=3657(\mathrm{NH}), 2196(\mathrm{CN}), 1661(\mathrm{CO}), 1597(\mathrm{C}=\mathrm{N})$, $1494(\mathrm{Ph}) ;{ }^{1} \mathrm{H}-\mathrm{NMR}\left(200 \mathrm{MHz}, \mathrm{CDCl}_{3}\right) \delta(\mathrm{ppm}): 1.95$ (s, 3H, $\left.\mathrm{CH}_{3}\right), 3.8\left(\mathrm{~s}, 2 \mathrm{H}, \mathrm{CH}_{2}\right), 5.48(\mathrm{~s}, 1 \mathrm{H}, \mathrm{CH}), 7.24-7.52(\mathrm{~m}, 15 \mathrm{H}$, Ar-H), 8.29 (s, 1H, NH). MS (EI, $70 \mathrm{ev)} \mathrm{m} / \mathrm{z}(\%)=420$ $\left(\mathrm{M}^{+}-\mathrm{CN}, 2.87\right), 418$ (4.3), 394 (2.88), 370 (3.5), 360 (3.17), 314 (6.36), 293 (10.9), 275 (6.95), 262 (13.7), 200 (5.99), 185 (14.0), 174 (9.56), 156 (4.01), 128 (11.3), 105 (76.7), 91 (38.6), 77 (100.0). Anal. Calcd. for $\mathrm{C}_{28} \mathrm{H}_{22} \mathrm{~N}_{4} \mathrm{O}_{2}$ (446.5): C, $75.32 ; \mathrm{H}, 4.97 ; \mathrm{N}, 12.55 \%$. Found: $\mathrm{C}, 75.38 ; \mathrm{H}, 5.06 ; \mathrm{N}$, $12.67 \%$.

Synthesis of 4,6,9-trihydro-3-methyl-1,4-diphenylpyrazolo $\left[3^{\prime}, 4^{\prime}, 2,3\right]$ pyrano[6,5-d]pyrimidine-5-one (16). An equimolar amounts of $(1,5 \mathrm{mmol})$ and formic acid (5 $\mathrm{mmol})$ in absolute ethanol $(30 \mathrm{~mL})$ was refluxed for $2 \mathrm{~h}$. 
Potassium carbonate $(10 \%, 10 \mathrm{~mL})$ and hydrogen peroxide $(5 \mathrm{~mL})$ were added to the reaction mixture and continued refluxing for further one hour. The reaction mixture was concentrated and left to cool at room temperature overnight for complete precipitation. The separated solid was collected by filtration, and recrystallized from aqueous ethanol to yield compound 16 . Yield (42.2\%); brown crystals; $\mathrm{mp} 120^{\circ} \mathrm{C}$; IR $(\mathrm{KBr}): v / \mathrm{cm}^{-1}=3061(\mathrm{NH}), 1659(\mathrm{CO}$, amidic $), 1599(\mathrm{C}=\mathrm{N})$, $1496(\mathrm{Ph}) ;{ }^{1} \mathrm{H}-\mathrm{NMR}\left(200 \mathrm{MHz}, \mathrm{CDCl}_{3}\right) \delta(\mathrm{ppm}): 1.96$ (s, 3H, $\left.\mathrm{CH}_{3}\right), 4.79$ (s, 1H, CH-Ph), 7.18-7.36 (m, 10H, Ar-H), 7.63 $(\mathrm{s}, 1 \mathrm{H},-\mathrm{CH}=\mathrm{N}), 10.02(\mathrm{~s}, 1 \mathrm{H}, \mathrm{NH}) . \mathrm{MS}(\mathrm{EI}, 70 \mathrm{ev}) \mathrm{m} / \mathrm{z}(\%)=$ $358\left(\mathrm{M}^{+}+2,0.52\right), 357\left(\mathrm{M}^{+}+1,0.2\right), 346(1.7), 320(6.5), 304$ (10.8), 262 (100.0), 185 (43.7), 174 (42.3), 128 (18.7), 107 (16.2), 91 (4.2), 77 (12.4). Anal. Calcd. for $\mathrm{C}_{21} \mathrm{H}_{16} \mathrm{~N}_{4} \mathrm{O}_{2}$ (356.38): C, 70.77; H, 4.53; N, 15.72\%. Found: C, 70.83; H, $4.61 ; \mathrm{N}, 15.77 \%$.

Synthesis of 5-amino-4,9-dihydro-3-methyl-1,4- diphenyl pyrazolo $\left[3^{\prime}, 4^{\prime}, 2,3\right]$ pyrano $[6,5-d]$ pyrimidine (17). Equimolar amounts of $(1,5 \mathrm{mmol})$ and formamid $(5 \mathrm{mmol})$ in dimethylformamide $(30 \mathrm{~mL})$ followed by few drops of piperidine the reaction mixture was refluxed for $6 \mathrm{~h}$, then cold and poured into ice cold water and neutralized by dilute hydrochloric acid for complete precipitation. The precipitated solid was filtered off, dried and recrystallized from aqueous ethanol to give 17. Yield $(62.7 \%)$; pale brown powder; mp $100^{\circ} \mathrm{C}$; IR (KBr): $v / \mathrm{cm}^{-1}=3059,3032\left(\mathrm{NH}_{2}\right)$, $1598(\mathrm{C}=\mathrm{N}), 1496(\mathrm{Ph})$. MS (EI, 70 ev) $\mathrm{m} / \mathrm{z}(\%)=340$ $\left(\mathrm{M}^{+}-\mathrm{CH}_{3}, 6.49\right), 262$ (100.0), 261 (38.6), 185 (75.3), 174 (41.5), 128 (33.1), 105 (13.7). Anal. Calcd. for $\mathrm{C}_{21} \mathrm{H}_{17} \mathrm{~N}_{5} \mathrm{O}$ (355.39): C, 70.97; H, 4.82; N, 19.71\%. Found: C, 71.09; H, $4.93 ; \mathrm{N}, 19.76 \%$.

\section{Sample preparation}

Each of the test compounds and standards were dissolved in $12.5 \% \mathrm{DMSO}$, at concentrations of $(500 \mu \mathrm{g} / \mathrm{mL})$. Further dilutions of the compounds and standards in the test medium were prepared at the required quantities.

\section{Culture of microorganisms}

Bacteria strains were supplied from Botany Department, Faculty of Science, Menoufia University, Shebin El-Koam, Egypt, namely Bacillus subtilis (ATCC 6633) (Gram- positive), Pseudomonas aeruginosa (ATCC 27853) (Gramnegative) and Streptomyces species (Actinomycetes). The bacterial strains were maintained on MHA (Mueller - Hinton agar) medium (Oxoid, Chemical Co., UK) for $24 \mathrm{~h}$ at $37^{\circ} \mathrm{C}$. The medium was molten on a water bath, inoculated with 0.5 $\mathrm{mL}$ of the culture of the specific microorganism and poured into sterile Petri dishes to form a layer of about 3-4 mm thickness. The layer was allowed to cool and harden. With the aid of cork-borer, cups of about $10 \mathrm{~mm}$ diameter were produced[28].

\section{Agar diffusion technique}

The antibacterial activities of the synthesized compounds were tested against Bacillus subtilis (Gram-positive), Pseudomonas aeruginosa (Gram-negative) and Streptomyces species (Actinomycetes) using MH medium (17.5 g casein hydrolysate, $1.5 \mathrm{~g}$ soluble starch, $1000 \mathrm{~mL}$ beef extract). A stock solution of each synthesized compound $(500 \mu \mathrm{g} / \mathrm{mL})$ in DMSO was prepared and graded quantities of the test compounds were incorporated in specified quantity of sterilized liquid MH medium. Different concentrations of the test compounds in DMF were placed separately in cups in the agar medium. All plates were incubated at $37^{\circ} \mathrm{C}$ overnight. The inhibition zones were measured after $24 \mathrm{~h}$. The minimum inhibitory concentration (MIC) was defined as the intercept of the grave of logarithm concentrations versus diameter of the inhibition zones[29,30].

\section{REFERENCES}

[1] A. A. Fadda, H. M. Hassan, Indian J. Chem., 29B, 1020 (1990)

[2] A. A. Fadda, A. M. Khalil, M. M. El-Habbal, Pharmazie 46, $743(1991)$

[3] A. A. Fadda, M. A. Hanna, M. M. Girges, Chem. Paper, 46, 244 (1992)

[4] R. H. Rigterink, US Patent 3,399,205 (1968); Chem. Abstr., 69, 96483h (1968)

[5] B. B. Dey, V. A. Kutti, Proc. Natl. Inst. Sci. India, 6, 641 (1940); Chem. Abstr., 36, 83 (1942)

[6] G. A. Cooke, W. J. Houlihan, US Patent, 3,978,086 (1976); Chem. Abstr., 85, 177481p (1976)

[7] T. Maruyama, S. Roshimoto, N. Kuroki, K. Konishi, Kogyo Kagaku Zasshi, 68, 1919 (1965); Chem. Abstr., 66, 66711 (1967); M. Zabradnik, Wiley \& Sons; New York (1992)

[8] A. A. Fadda, M. E. A. Zaki, F. A. Amer, K. Samir. Phosphorous, Sulfur and Silicon, 181, 1815 (2006)

[9] A. A. Fadda, E. Abdel-Latif, H. M. Mustafa, H. A. Etman, Russ. J. Org. Chem., 43, 443 (2007)

[10] A. A. Fadda, M. E. A. Zaki, Kh. Samir, F. A. Amer, Phosphorous, Sulfur and Silicon, 182, 1 (2007)

[11] A. A. Fadda, S. Bondock, W. Khalifa, Synth. Commun., 36, 1601 (2006)

[12] A. A. Fadda, M. E. A. Zaki, Kh. Samir, F. A. Amer, Chem. Heterocycl. Comp., 9, 1413 (2003)

[13] H. H. Tacconi, G. Gatti, G. Desimoni, J. Prakt. Chem., 322, $831(1980)$

[14] L. G. Sharanina, V. K. Promonenkov, V. P. Marshtupa, A. V. Pashchenko, V. V. Puzanova, Yu. A. Sharanin, N. A. Klyuev, L. F. Gusev, A. P. Gnatusina, Khim. Geterotsikl. Soedin., 6, 901 (1982)

[15] N. M. Smirnova, N. M. Cherdantseva, O. A. Burova, V. M. Nesterov, T. S. Safonova, Chem. Heterocycl. Comp., 811 (1990)

[16] B. Farbenfabriken, DE, 175415 (1906); Chem. Abstr., 1, 6240 (1907)

[17] R. Kreher, P. H. Wagner, Chem. Ber., 113, 3675 (1980)

[18] G. Schroeter, C. Sidler, M. Sulzbacher, R. Kanitz, Chem. Ber., 
$65,432(1932)$

[19] T. Kappe, H. P. Stelzel, E. Ziegler, Monatsh. Chem., 114, 953 (1983)

[20] G. Schroeter, E. Finck, Chem. Ber., 71, 671 (1938)

[21] G. Roma, M. Di Braccio, A. Carrieri, G. Grossi, G. Leoncini, M. G. Signorello, A. Carotti, Bioorg. Med. Chem., 11, 123 (2003)

[22] M. Ghate, R. A. Kusanur, M. V. Kulkarni, Eur. J. Med. Chem., $40,882(2005)$

[23] A. A. Fadda, H. M. Refaat, M. T. El-Zemaity, E. R. Biehl, Heterocycles, 43, 23 (1996)

[24] Shimamure, H.; Terajima, K.; Kawase, A.; Ishizuka, Y.; Kimura, I.; Kamya, A.; Kataoka, M.; Sato, M. Japan Kokai Tokyo Koho JP 05,112,559; Chem Abstr. 1993, 119, 160315k
[25] Taylor Jr., E. C.; Kalenda, N. W. J Am Chem Soc 1956, 78, 5108

[26] Robins, R. K. J Am Chem Soc 1956, 78, 784

[27] El-Tamany, E. H.; El-Shahed, F. A.; Mohamed, B. H. J Serb Chem Soc 1999, 64, 9

[28] J. H. Jorgensen, J. D. Jurnide, J. A. Washington Antimicrobial susceptibility tests. In: Manual of Clinical Microbiology, 7th ed. P. R. Muarry, E. J. Baron, R. C. Yolken, eds, American Society for Microbiology, Washington, DC, USA, pp 1526-1543 (1999)

[29] A. M. Janssen, J. J. Scheffer, A. B. Svendsen, Planta Med, 53, 395 (1987)

[30] Greenwood, Antimicrobial Chemotherapy, 4th ed, Oxford University press, New York, p. 114 (2000) 